\title{
Students' personal professional theories in competence-based vocational education: the construction of personal knowledge through internalisation and socialisation
}

Citation for published version (APA):

Schaap, H., De Bruijn, E., Van der Schaaf, M., \& Kirschner, P. A. (2009). Students' personal professional theories in competence-based vocational education: the construction of personal knowledge through internalisation and socialisation. Journal of Vocational Education \& Training, 61(4), 481-494.

https://doi.org/10.1080/13636820903230999

DOI:

10.1080/13636820903230999

Document status and date:

Published: 07/12/2009

Document Version:

Peer reviewed version

Please check the document version of this publication:

- A submitted manuscript is the version of the article upon submission and before peer-review. There can be important differences between the submitted version and the official published version of record. People interested in the research are advised to contact the author for the final version of the publication, or visit the DOI to the publisher's website.

- The final author version and the galley proof are versions of the publication after peer review.

- The final published version features the final layout of the paper including the volume, issue and page numbers.

Link to publication

\section{General rights}

Copyright and moral rights for the publications made accessible in the public portal are retained by the authors and/or other copyright owners and it is a condition of accessing publications that users recognise and abide by the legal requirements associated with these rights.

- Users may download and print one copy of any publication from the public portal for the purpose of private study or research.

- You may not further distribute the material or use it for any profit-making activity or commercial gain

- You may freely distribute the URL identifying the publication in the public portal.

If the publication is distributed under the terms of Article $25 \mathrm{fa}$ of the Dutch Copyright Act, indicated by the "Taverne" license above, please follow below link for the End User Agreement:

https://www.ou.nl/taverne-agreement

Take down policy

If you believe that this document breaches copyright please contact us at:

pure-support@ou.nl

providing details and we will investigate your claim.

Downloaded from https://research.ou.nl/ on date: 26 Apr. 2023 
This article was downloaded by: [Schaap, H.]

On: 7 December 2009

Access details: Access Details: [subscription number 917469453]

Publisher Routledge

Informa Ltd Registered in England and Wales Registered Number: 1072954 Registered office: Mortimer House, 3741 Mortimer Street, London W1T 3JH, UK

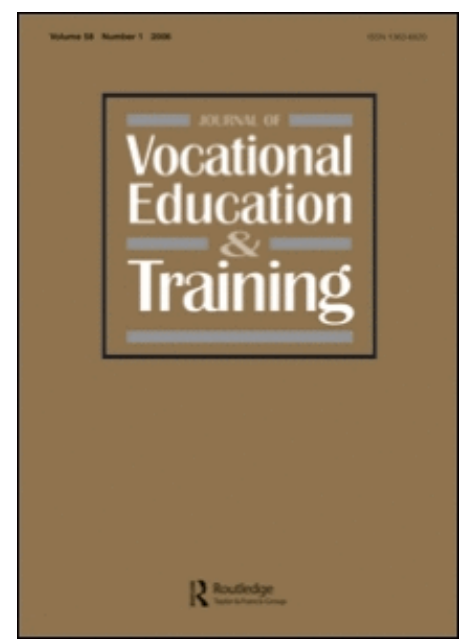

\section{Journal of Vocational Education \& Training}

Publication details, including instructions for authors and subscription information:

http://www.informaworld.com/smpp/title $\sim$ content=t716100716

\section{Students' personal professional theories in competence-based vocational education: the construction of personal knowledge through internalisation and socialisation}

H. Schaap ${ }^{\text {a; }}$ E. de Bruijn ${ }^{\text {a; }}$ M. F. Van der Schaaf ${ }^{\text {a; }}$ P. A. Kirschner ${ }^{\text {b }}$

${ }^{a}$ Utrecht University, Utrecht, the Netherlands ${ }^{\text {b }}$ Open University of the Netherlands, DL Heerlen, the

Netherlands

Online publication date: 07 December 2009

To cite this Article Schaap, H., de Bruijn, E., Van der Schaaf, M. F. and Kirschner, P. A.(2009) 'Students' personal professional theories in competence-based vocational education: the construction of personal knowledge through internalisation and socialisation', Journal of Vocational Education \& Training, 61: 4, 481 - 494

To link to this Article: DOI: $10.1080 / 13636820903230999$

URL: http://dx.doi.org/10.1080/13636820903230999

\section{PLEASE SCROLL DOWN FOR ARTICLE}

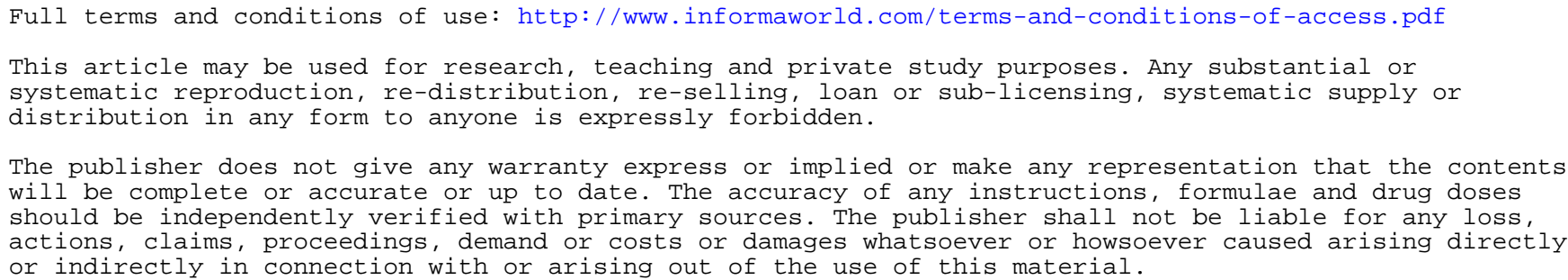




\title{
Students' personal professional theories in competence-based vocational education: the construction of personal knowledge through internalisation and socialisation
}

\author{
H. Schaap ${ }^{a *}$, E. de Bruijn ${ }^{a}$, M.F. Van der Schaaf ${ }^{a}$ and P.A. Kirschner ${ }^{b}$ \\ ${ }^{a}$ Utrecht University, Utrecht, the Netherlands; ${ }^{b}$ Open University of the Netherlands, \\ DL Heerlen, the Netherlands
}

(Received 27 October 2008; final version received 20 July 2009)

\begin{abstract}
Competence-based vocational education is based on a constructivist learning paradigm, where the development of students' personal professional knowledge is emphasised. However, there is a lack of insight into how students construct their own professional knowledge and what the content and nature of personal professional knowledge is. This article elaborates the concept Personal Professional Theory (PPT): a personal knowledge base in which professional knowledge and beliefs are internalised. PPTs are built upon a combination of declarative and procedural knowledge and are stored in the long-term memory. Furthermore, knowledge in PPTs refers to compiled knowledge which can be specified and applied to different professional situations. These PPTs develop through an interrelated process of internalisation and socialisation, in which students grow into the existing body of shared knowledge and collective norms, values and beliefs of professionals of an occupational domain. It is concluded that the elaboration of PPTs can be used to stimulate and monitor personal professional knowledge development in vocational education, but further research into the content and nature of PPTs is required.
\end{abstract}

Keywords: personal professional theories; knowledge and beliefs; declarative and procedural knowledge; personal knowledge development; internalisation and socialisation

\section{Knowledge in competence-based vocational education}

Vocational education is subject to constant social changes, technical developments and organisational demands. The increased use of new information and communication technologies and the changing perspective on employees as flexible and employable professionals (Wagner 1994), have caused many countries to redefine the key competences that are necessary for adequate professional behaviour (Achtenhagen and Grubb 2001). In the current knowledge-based societies and labour markets, professionals not only need specific technical and formal knowledge, but also need well-developed professional skills and attitudes for lifelong learning (Maes 2004). As a response to these changing professional demands, a competence-based qualification structure has been adopted in vocational education, for example in the Netherlands, Germany, France, Great Britain and Australia (Achtenhagen and Grubb 2001; Billet

*Corresponding author. Email: h.schaap@uu.nl 
2000; de Bruijn 2004; Nijhof and van Esch 2004; Seezink, Poell, and Kirschner 2009; Weigel, Mulder, and Collins 2007).

Competence-based vocational education is based upon a constructivist learning paradigm and aims to reduce the gap between training programmes in vocational schools and the needs of the labour market (Rauner 2007; Simons, van der Linden, and Duffy 2000; Tillema, Kessels, and Meijers 2000). In competence-based vocational education authentic key issues and problems are integrated in the training programmes, so that students learn how to deal with these problems (Guile and Griffiths 2003). Competences are conceived as more or less organised wholes of knowledge, skills and attitudes (Lizzio and Wilson 2004; van der Sanden and Teurlings 2003) that are required for adequate fulfilment of professional tasks (Eraut 1994; Hager and Gonczi 1991). The underlying idea is that in competencebased vocational education students develop competences that are needed in (future) professions as well as for lifelong learning (Biemans et al. 2004). The development of professional competences is a main objective of competence-based vocational education. Learning is viewed as giving meaning to experiences in a process of continuous progressive recontextualisation (Seezink, Poell, and Kirschner 2009).

A major problem in competence-based vocational education is, however, that it is unclear how knowledge is internalised by students in a personal professional knowledge base (van der Sanden and Teurlings 2003). This is problematic, because learning is not effective when there is no explicit attention to the internalisation of different types of knowledge with and in personal professional knowledge (Eraut 1994). As students in vocational education have to internalise various types of knowledge, explicit attention to the internalisation of knowledge is crucial. For example, a combination of explicit and codified knowledge as well as situational and episodic knowledge is required for adequate professional performance (Guile and Young 2003). When learning in the workplace, students adapt and internalise cultural features, such as norms, values and beliefs of an occupational domain. The transfer and integration of these shared norms, values and professional beliefs conceived from workplaces to vocational schools seem to be problematic (Achtenhagen and Grubb 2001; Boreham 2004; Eraut 1994; Poortman 2007).

To generate insight in the internalisation of knowledge in competence-based vocational education, this article elaborates the concept Personal Professional Theory (PPT). A PPT is a personal professional knowledge base that serves as frame of reference in the process of internalising professional knowledge and beliefs. It is postulated that the development of PPTs means growing into a specific occupational domain, through the internalisation of shared knowledge and collective norms, values and beliefs of professionals. The emphasis on the internalisation of knowledge can be useful for competence-based vocational education, because students often learn the norms and values of an occupational domain in an implicit way (Achtenhagen and Grubb 2001). The function of internalisation is twofold: PPTs develop through a process of internalisation and serve at the same time as frame of reference in the process of internalising new professional knowledge and beliefs. In this article the construct PPT will be defined by answering two leading questions: (1) what is the nature and content of Personal Professional Theories; and (2) how do Personal Professional Theories develop? The main goal of this article is to show the value of Personal Professional Theories for competence-based vocational education. 


\section{Students' Personal Professional Theories}

PPTs have two functions, namely as a frame of reference through which professionals acquire and interpret new knowledge and for directing professional behaviour. The relation, however, between personal knowledge and professional behaviour is complex (Argyris and Schön 1978; Beijaard and Verloop 1996; Levin and He 2008). The content of PPTs consists of a combination of propositional, conceptual knowledge and personal beliefs. This article conceives knowledge, in general, as personal, which can be used in different situations and which is directly related to the ability to learn (Becker and Steele 1995). Knowledge in competence-based vocational education, then, is conceived as the result of interactions between different individuals in schools, workplaces and professional organisations (Simons, van der Linden and Duffy). Knowledge, then, is not seen in an absolute or static form, it: (1) is personal and subjective; (2) is directly related to the performance and actions of people; and (3) has personal meaning (Nonaka and Takeuchi 1995). Personal beliefs form a subjective truth, which is constantly validated by inferring and confronting own beliefs (Drucker 1993). Beliefs are seen as filters through which new knowledge is acquired (Putnam and Borko 2000).

This article agrees with Pajares (1992), who postulates that knowledge and beliefs are inextricable related. The symbiotic relation between knowledge and beliefs primarily refers to personal knowledge (Kagan 1990). Because PPTs refer to personal knowledge construction, they have a broader scope than theories of action as elaborated by Argyris and Schön $(1974,1978)$. Where a theory of action is defined as 'a theory of deliberate human behavior which is for the agent a theory of control but which also serves to explain or predict his behavior' (Argyris and Schön 1974, 6), PPTs refer to the connection and internalisation of various types of knowledge and beliefs (Cornett, Yeoties, and Terwilliger 1990; Kelchtermans and Vandenberghe 1994). A theory of action is specific for deliberate human behaviour. The connectedness of propositional and conceptual knowledge and personal beliefs implies that change in one aspect of the theory entails changes in the theory elsewhere. A theory, in general, is 'not necessarily accepted, good or true; it is only a set of interconnected propositions that have the same referent - the subject of the theory' (Argyris and Schön, 1974).

This article elaborates five main features of PPTs. Each feature is concerned with the nature of knowledge and knowledge development. A PPT (1) consists of declarative and procedural knowledge; (2) is stored in the long-term memory; (3) refers to compiled knowledge and is used in the process of tacit knowing; (4) is based upon different types of knowledge, such as formal theories, work-process knowledge, practical knowledge and shared knowledge, norms, values and beliefs of an occupational domain; and (5) can be specified and applied to different situations. These features are elaborated in the following five sections.

\section{Declarative and procedural knowledge}

PPTs consist of a combination of declarative and procedural knowledge. Declarative knowledge refers to the factual information that a person knows and can report, which can be represented as a network of small units of primitive knowledge called chunks. Procedural knowledge is represented by a large number of productions or production rules, which are condition-action units that respond to various conditions for which specific actions are required (Anderson and Schunn 2000). The production rules are condition-action units, referring to causal relations among two different 
events (an 'if-then' strategy). The production rules form together a production system. Procedural knowledge refers, then, to knowledge that is fundamental for professional actions, such as knowing which knowledge is important in a certain situation and how to use it.

Anderson and Schunn (2000) refer to relatively simple and specific cognitive tasks like using heuristics in simple arithmetic assignments, to illustrate the existence and function of both declarative and procedural knowledge. However, the problems to which professionals are confronted are complex and comprehensive in nature (DarlingHammond and Sykes 1999). Professionals need to anticipate adequately when facing occupational core problems, which refer to an authentic problem, where different perspectives are relevant and where no direct solution is available (Zolingen et al. 1999). It can therefore be discussed whether procedural knowledge in fuzzy, complex, ambiguous and value-laden situations is stored in an identical way as Anderson and Schunn account for (Winitzky and Kauchak 1995). This may have influence on the nature of the production systems in PPTs. Due to the complexity of professional tasks and situations the production systems in PPTs can be (1) general or specific; and (2) complex and simple in nature, depending on the nature of certain tasks or situations. It is noticeable that the nature of professional tasks (i.e. complexity or specificity) also depends on the developed PPT and the experiences and perceptions of a professional.

\section{Long-term memory}

This article postulates that PPTs are stored into the long-term memory, because the knowledge in PPTs is situated in different internal representations or schemes. It is assumed that professionals store their knowledge in a schematic way; they construct internal representations of what they know (Meijer 1999). These schemes can be constructed either distributed or parallel to each other (Hinton and Anderson 1981). From research into the human cognitive architecture it is known that both long-term memory and working memory are integrally related in storing knowledge. Long-term memory incorporates a massive knowledge base that is central to all of our cognitively-based activities, while working memory is where cognitive processing occurs (Kirschner, Sweller, and Clark, 2006; Meijer 1999). The knowledge in long-term memory is permanently incorporated in the mind of a person (Anderson 1980). The nature of knowledge in long-term memory is organised, stable and meaningful (Mayer 1981).

In the process of storing new information, the knowledge in working memory remains temporarily active (Atkinson and Shiffrin 1968; Baddely and Hitch 1974). When professionals are confronted with complex occupational problems, they have to 'call up' relevant elements from their long-term memory into their working memory, in order to establish a way for adequate performance. Professionals then, select and use appropriate facts (declarative knowledge) and corresponding procedures (procedural knowledge), which are stored in their PPTs and thus in the long-term memory.

\section{Formal knowledge, practical knowledge and work-process knowledge}

The knowledge base of a person is made up of different types of knowledge (De Jong and Ferguson-Hessler 1996). This article conceives formal-, practical- and work-process knowledge as relevant types of knowledge in the specific context of vocational education and occupational learning (Griffiths and Guile 2003). 
Formal knowledge is conceived as the fundamental basis of every profession; occupations are based on systematic knowledge, acquired through formal training and experiences (Wilensky 1964). De Jong and Ferguson-Hessler (1996) refer to conceptual knowledge as static knowledge about facts, concept and principles that can be applied in a specific domain. Formal knowledge is highly explicit, objective and can be expressed in formal and systematic language and can be stored in complex datasets, articles, handbooks and specific instructions (Nonaka and Takeuchi 1995). This implies that formal knowledge is transferable between different actors and entities. Formal knowledge is therefore conceived as explicit, coherent and systematic knowledge (Eraut 1994).

One of the major ways of knowing in the changing landscape of professional work is work-process knowledge which is generally defined as a combination of practical and formal or propositional knowledge (Boreham 2002; Rauner 2007). Work-process knowledge is conceived as an integral and comprehensive concept, which is conducted from work processes in organisations on the one hand, and from direct experience of the work itself on the other (Griffiths and Guile 2003). In this view, work-process knowledge should assist learners in addressing complex issues they confront in the professional workplace. Subsequently, rather than 'offering learners "inert" knowledge which does not assist learners in addressing the complex issues they confront in the workplace it is important to assist learners in developing ways of knowing which are integral to work activity' (Griffiths and Guile, 2003, 62). Additionally, Boreham (2004) refers to work-process knowledge as knowledge about the organisational environment and the professional work context and work procedures. Work-process knowledge: (1) implies understanding the work process in the organisation as a whole, it is a system-level understanding of the organisation; (2) is active knowledge, which is used directly in professional actions; (3) is constructed during professional activities, in for example problem-solving situations; and (4) is a synthesis of theoretical (i.e. codified) and experiential (i.e. episodic) knowledge. Rauner (2007) refers to work-process knowledge as directly needed in the work process, acquired in the work process itself and pointed to a complete work process. Workprocess knowledge, then, is a combination of practical and formal knowledge.

Practical knowledge is a comprehensive concept which is used in different professional domains and research paradigms, for example in the domain of vocational education (Rauner 2007) and in the domain of teacher education and research (Beijaard and Verloop 1996; Munby, Russell, and Martin 2001; Verloop, van Driel, and Meijer 2001). In the domain of teacher education and research, practical knowledge is generally defined as all professional related insights that are potentially relevant to teachers' activities (Verloop, van Driel, and Meijer 2001). Practical knowledge is defined as a combination of declarative and procedural knowledge and beliefs, including norms and values (Beijaard and Verloop 1996). However, in teacher education, practical knowledge is operationalised in various ways, depending on the research purpose (Beijaard and Verloop 1996). Meijer, Verloop and Beijaard (2002) for example refer to teachers' practical knowledge as personal, contextual and tacit knowledge, which is based upon experiences and which underlies teachers' actions. Moreover, they state that dynamic and performance-related interactive cognitions are part of practical knowledge. Interactive cognitions, as situated between knowledge and beliefs, and concrete behaviour, are constructed during professional actions and are located in the working memory. In the domain of vocational education, practical knowledge is defined as subjective and tacit knowledge, embedded in the logic of 
practice (Rauner 2007). Practical knowledge exists in interaction with objects, persons, procedures or other artefacts. Besides a sense of interpretive understanding and methodological knowledge, practical knowledge comprises motivational or emotional knowledge as well (Rauner).

This article postulates that interactive cognitions are not part of PPTs, because of the temporary and dynamic nature of interactive cognitions. PPTs are stable in nature and refer to personal professional knowledge, which is fundamental for professional actions, and is stored in the long-term memory. It is particularly the knowledge in the working memory which refers to interactive cognitions (Meijer, Verloop, and Beijaard 2002). Indeed, interactive cognitions are important in the actual performance of professionals (Baddely and Hitch 1974), while the knowledge in PPTs can be specified and applied to different professional situations. That implies that PPTs can be interpreted independently from specific situations.

Formal knowledge, practical knowledge and work-process knowledge, in their relatedness and their tacit and dynamic nature, show their value as sources for personal professional knowledge development. Because PPTs consist of internalised knowledge, no distinction can be made between different types of knowledge, such as formal knowledge, practical knowledge and work-process knowledge. This article therefore postulates a somewhat different perspective on personal knowledge development than the one that for example Eraut (1994) and de Jong and Ferguson-Hessler (1996) have developed: personal professional knowledge in PPTs cannot be separated into different types of knowledge. In the process of internalisation, different types of knowledge are assimilated or accomodated into knowledge structures (Piaget 1950). It is the internalisation of different types of knowledge that is a crucial aspect of personal professional knowledge development. Formal knowledge, work-process knowledge and practical knowledge, in their complexity and interrelatedness, are sources for personal professional knowledge development. Nevertheless, it is indeed possible to describe qualities of personal professional knowledge, because the qualities of knowledge are independent from the types of knowledge (de Jong and Ferguson-Hessler 1996). Qualities of knowledge refer to properties of knowledge. PPTs can thus only be described by identifying relevant qualities of personal professional knowledge.

\section{Knowledge compilation, tacit knowledge and tacit knowing}

The personal professional knowledge in PPTs refers to compiled knowledge. Knowledge compilation is a process in which the nature of knowledge changes over time, when the amount of experience increases, knowledge becomes stored in large components that already entail other concepts and relations between these concepts (Anderson 1980; Meijer 1999). Knowledge compilation views personal professional knowledge as a hierarchical structure in which knowledge is layered and related to core concepts. It is assumed that professionals, with frequent experiences, can respond quickly and efficiently to complex situations and tasks. Winitzky and Kauchak (1995) found that the structural knowledge base of pre-service teachers, measured with open-ended concept maps, became smaller and simpler over time. They state that because 'subjects were engaged in integrating declarative with procedural knowledge, the maps reflected this on-going process of knowledge compilation and teachers no longer needed to hold this information in working memory, and it ceased to appear on their maps' (Winitzky and Kauchak 1995, 222). Because the teachers have combined their productions into 
few, more effective large knowledge concepts, they required fewer items on their maps to represent what they knew how to do.

It is often assumed that increasing expertise and experiences are inherent with the development of tacit knowledge. Tacit knowledge refers to actual knowledge which is embedded into knowledge-in-action of professionals (Schön 1983; de Jong and Ferguson-Hessler 1996). Polanyi (1958) postulates that people know more than they can tell and explicate. It can then be questioned whether the amount of tacit knowledge increases when a person becomes experienced. The ability to verbalise personal professional knowledge decreases with increasing experience and skill development (Berliner 1995). On the other hand, experts or specialists on a specific task or domain can have more systematised and well-founded PPTs than novices or non-specialists (van der Krogt and Vermulst 2000): they 'do not say that novices do not use these theories, but that these theories can be assumed to be less explicit, less coherent, less well-founded and less focussed on their specific place in the occupational system' (van der Krogt and Vermulst 2000, 125). Experts work on the basis of relatively elaborated PPTs while novices are less likely to have such crystallised views on their professional activities. Experts are unaware of the fact they possess certain personal knowledge. However, experienced professionals can explicate their knowledge when a situation requires it or when adequate stimuli are used (Schön 1983; Boshuizen and Schmidt 1992). This seems contradictory: personal professional knowledge becomes more tacit when a professional becomes more experienced, while professionals can explicate and articulate their personal professional knowledge when adequate stimuli are used.

However, a distinction can be made here between tacit knowledge and tacit knowing. Tacit knowing refers to an active process in which knowledge is constructed in action itself, while tacit knowledge refers to actual knowledge which is embedded into knowledge-in-action of professionals. In tacit knowing, two terms are always embedded and combined: the proximal and the distal (Polanyi 1983). Proximal refers to knowledge that one may not be able to tell, because it refers to personal feelings, while distal refers to phenomena which are outside a person. What a person can say is a distal term, what a person experience (i.e. physically feel) is a proximal term. When the attention of a person shifts from proximal to distal terms, the meaning of a situation or object changes: there is a semantic difference between thinking and explicating. Polanyi refers to the semantic aspect of tacit knowing as the process in which meaning occurs in interaction between people and objects in a situation. Tacit knowing, seen as a meaningful relationship between a distal and a proximal term, therefore is the understanding of an entity in the direct environment of a person.

This article postulates that PPTs refer to compiled knowledge. The process of knowledge compilation is different than the development of tacit knowledge, because compiled knowledge can be made visible, but in a different manner: fewer but more relevant concepts are used to describe structural knowledge, while these concepts at the same time comprise more knowledge and knowledge structures. For the development of PPTs this implies that the nature of personal professional knowledge change when a person becomes more experienced. Tacit knowing is referred to the knowledge that is constructed in the actual performance and actions of professionals. An aspect of tacit knowing is then the integration of declarative and procedural knowledge. PPTs, thus, do not primarily refer to tacit knowing since tacit knowing refers to an active and continue constructive process, which exists in actions itself, while PPTs are the personal knowledge base which forms the basis for professional actions. 


\section{Situated cognition}

Situated cognition refers to knowledge as a product of the activities and situations in which it is produced (Brown, Collins, and Duguid 1989; Lave and Wenger 1991). Knowledge, then, is always situated and under construction: it progressively develops through new situations (Meijer 1999). Subsequently, the relation between knowledge and a certain situation is reciprocal, because knowledge is inherently built up to situations and simultaneously when knowledge is used in a situation, the understanding of a situation changes. There is, however, discussion concerning the extent in which knowledge can be seen as independent from a situation. Brown, Collins and Duguid (1989) have postulated that knowledge that is seen independently from a situation can be inappropriate or even invalid, while Anderson, Reder and Simon (1996), and Schön (1983) have stated that knowledge can be both partly context-dependent and partly context-independent.

PPTs consist of personal professional knowledge that can be applied in different situations. In this respect this article agrees with Anderson, Reder and Simon (1996) and Schön (1983): knowledge can also be interpreted and stored independently from specific situations. In other words: PPTs are transferable between different situations, while situated knowledge refers to contextualised knowledge (van Oers 1998). A PPT can indeed be specified and applied to different situations. The extent to which the knowledge in a PPT and the integration between declarative and procedural knowledge match with the situation determines to a large extent the quality of a PPT at a certain moment. Also, the specific context and the complexity of the tasks determine the extent is which personal professional knowledge comes into a situation and how new knowledge can be derived from a specific situation.

In the next section, the development of PPTs will be clarified by using two perspectives: (1) a sociological perspective on knowledge development, which refers to the interrelated process of internalisation and socialisation; and (2) a cognitive psychological perspective, in which the development of declarative and procedural knowledge is announced.

\section{Development of Personal Professional Theories}

\section{Internalisation and socialisation}

The development of PPTs, as discussed in the previous sections, implies that shared knowledge and collective norms, values and beliefs of a professional domain are internalised into an individual's PPT through a process of socialisation from the domain's Collective Professional Theory (CPT). A CPT consists of shared knowledge and collective norms, values and beliefs of professionals working in a certain occupational domain (de Bruijn and Nieuwenhuis 1994; Wilensky 1964) and distinguishes one occupational domain from another (Guile and Griffiths 2003; Shulman 2006; Wilensky 1964). A CPT reflects a certain degree of consensus among the members of a community of professionals (de Bruijn and Nieuwenhuis; Wilensky 1964) achieved through a collective process of negotiation of meaning (Wenger 1998). It has become widely accepted that knowledge, norms, values and beliefs are shared by a community of practitioners at a certain time and place, and thus are socially situated constructs. However, this combination of different aspects in a CPT can only be formulated in a relative way. Within the CPT of a specific domain there is the possibility of several schools of thought. These different schools of thought, which are appropriate in the same occupational 
domain, can occur between different organisations or different regions (Wenger 1998). For example, distinctions between firm-based practices are more significant as the distinction between different occupations (Lave and Wenger 1991).

Without undermining the dynamic nature of professions - and therefore the CPT of an occupational domain - this article assumes that CPTs exist with a shared understanding of knowledge, norms, values and beliefs referring to professional behaviour collectively perceived as adequate. The CPT of a specific occupational domain explains why there are similarities between the PPTs of professionals working in the same occupational domain. However, PPTs are, because of their personal nature, at the same time personally coloured and subjective. Socialisation refers to the process of growing into the CPT; the relevant professional norms, values and beliefs are translated and internalised into PPTs. Becoming a professional means adapting and internalising the shared knowledge and collective norms, values and beliefs of a CPT (Lave and Wenger 1991; Wenger 1998). This process results in a professional theory of one's own - the PPT - which consists of a personal interpretation of these aspects of a CPT.

Internalisation is elaborated in different streams, such as the development of psychological functions during child development (Vygotsky 1978) and knowledge development within creative and innovative organisations (Nonaka and Takeuchi 1995). Both theories are used to clarify the process of internalisation of knowledge in PPTs. From the perspective of child development, internalisation is conceived as a process in which an external operation is internally reconstructed (Vygotsky). The process of internalisation consists of a series of three transformations: (1) an external activity is reconstructed and begins to occur internally; (2) an interpersonal process is transformed into an intrapersonal process; and (3) the transformation of an interpersonal process into an intrapersonal process is the result of a long series of development activities. According to Vygotsky, internalisation is a process in which the meanings and functions of a certain task or gesture are created at first by an objective situation in which the child has only an object-oriented movement and in which a child has to solve a certain problem solely. Vygotsky postulated that the child needs another person, like a mother or a peer, to successfully attempt the task or gesture. Then, the meaning and functions of the task or gesture are not created in an objective situation in which the child has an object-centered focus: the meaning and functions are then created in interaction by and with the people who surround the child.

From the perspective of knowledge development in organisations, internalisation is positioned in a model of four types of knowledge conversion and accumulation: socialisation, externalisation, combination and internalisation (Nonaka and Takeuchi 1995). In this model, personal and subjective knowledge is confronted and combined with formal and explicit knowledge in order to create new knowledge. Internalisation is, in this context, conceived as an individual strategy to broaden, extend and reframe personal professional knowledge. According to these authors, internalisation is a process in which explicit knowledge becomes personal and subjective knowledge. Personal professional knowledge development takes place when experiences through socialisation, externalisation and combination become personal in the form of mental schemes. Nonaka and Takeuchi postulate that both mental and physical experiences are important in the process of internalisation, because then professionals are stimulated to actively use their existing mental schemes in new situations and different contexts.

This article postulates that internalisation is an important psychological process in the development of PPTs. In the context of the development of PPTs, internalisation 
refers to the process of embodying various types of knowledge in PPTs. Internalisation is an active, continuous and dynamic process in which people are stimulated to broaden, extent or reframe their PPTs.

\section{Development of declarative and procedural knowledge}

The development of PPTs constitutes a dynamic action-feedback-revision process, in which professionals take some actions, observe its feedback and refine subsequent actions (Anderson 1980; Winitzky and Kauchak 1995). This development process starts when a certain stimulus (e.g. a complex problem) activates perceived relevant declarative and procedural knowledge of the PPT, which are stored in the long-term memory (Fitts and Posner 1967). Anderson and Schunn (2000) refer to this process as firing: production rules 'fire' in response to a certain task. Perceived relevant information is then brought into the working memory in which discrepancies between declarative knowledge, procedural knowledge and the actual situation will be detected and reduced.

Goal structures play an important role in the development of procedural knowledge because they determine the overall organisation and structure of cognitions, whereby each task can be decomposed into sub-goals (Anderson and Schunn 2000). According to Anderson and Schunn, sub-goals impose 'a strong order on the way in which information is accessed and skills are applied' (Anderson and Schunn 2000, 5). The existence of sub-goals implies that a professional situation activates specific purposeful behaviour, which relates to specific sub-goals. This process of relating existing knowledge structures to sub-goals produces temporary declarative knowledge and takes place in the working memory. When a relevant production system is retrieved or actually developed, the developed declarative knowledge is integrated in a comprehensive composition of procedural knowledge: the production system.

When carrying out a professional task, professionals select the most adequate productions and relate the selected productions with others into a set of procedural knowledge. Each production will be evaluated and stored in the working memory. The knowledge, which is 'called up' from the long-term memory, is used by the professional. Note here that the way how PPTs are used in professional situations depends on several factors. During the process of retrieving declarative and procedural knowledge as well as the actual performance and actions of the professionals, knowledge development takes place (Anderson and Schunn 2000; Fitts and Posner 1967). The relevant declarative knowledge and the developed procedural knowledge, which can be retrieved from the particular task, are then stored in the long-term memory. The transfer of knowledge from working memory to long-term memory after complex actions or performances, results in a change in a PPT.

\section{Conclusion and discussion}

This article elaborated the PPTs as a relevant concept for emphasising the role of professional knowledge in competence-based vocational education. In this article we have substantiated that PPTs (1) consist of declarative and procedural knowledge; (2) are stored in the long-term memory; (3) refer to compiled knowledge; (4) are built upon different types of knowledge, such as formal theories, work-process knowledge, practical knowledge and shared knowledge, collective norms, values and beliefs of an occupational domain; and (5) can be specified and applied to different 
professional situations. The development of PPTs refers to a process in which elements of a CPT - shared knowledge and collective norms, values and beliefs are internalised. This implies that PPTs are always personal and subjective.

The elaboration of PPTs can be used to analyse the development of students' personal professional knowledge during education, training and/or internships. During an internship it is for example expected that students adapt and internalise cultural features of a particular occupational domain (Billet 2001; Illeris 2003). The internalisation of these shared norms, values and professional beliefs conceived in a PPT can be supported by making PPTs of students explicit and through stimulating reflection on personal professional knowledge growth. By close monitoring of the development of PPTs teachers and trainers can gain insight in the internalisation of knowledge by individual students. This is a formative application function of PPTs (Huijts, de Bruijn and Schaap, accepted).

For a formative application function of PPTs, a valid and reliable measurement and assessment procedure needs to be developed (Biemans et al. 2004; Tillema, Kessels, and Meijers 2000). The personal nature of PPTs has serious implications for the development of assessment procedures and instruments. For a complete measurement and assessment of PPTs, a multi-method approach where several methods are used and triangulated is required (Meijer, Verloop, and Beijaard 2002). Examples of different suitable methods are concept maps, stimulated recall interviews, interviews (Beijaard and Verloop 1996; Meijer 1999) and narrative self-descriptions (Kelchtermans and Vandenberghe 1994). To validly assess whether PPTs are well developed and representative for a professional in a certain occupational domain it might be useful to involve experts, which can be for example experienced teachers, trainers from the field or practitioners, in the assessment procedure.

The elaboration of the construct PPT raises the question when PPTs show quality and relevance. A study of Huijts, de Bruijn and Schaap (accepted) shows that richer PPTs are more relevant for the occupational domain. However, determining the quality of PPTs is a complex process. Firstly, it is still unknown which qualities can be used to determine the quality of PPTs. Previous research shows a diffuse field of qualities of knowledge. For example, De Jong and Ferguson-Hessler (1996) postulated that five qualities can be used to determine the overall quality of personal knowledge, namely: level, structure, automation, modality and generality. Another example can be found in the work of Zanting, Verloop and Vermunt (2003), who stated that knowledge of teachers can be separated into (1) an absolute versus a situational dimension (knowledge can be described with or without an indication of its situational character); and (2) a descriptive versus an analytical dimension (i.e. facts versus underlying reasons and motives). Secondly, another way to determine the quality of PPTs is the elaboration of differences and similarities between a PPT and a CPT. It can be stated that the more similarities a PPT shows, the more quality a PPT has for the particular occupational domain (Huijts, de Bruijn and Schaap, accepted; Verloop, van Driel, and Meijer 2001). As the distinction between a personal knowledge base and a collective knowledge base is arbitrary (Krause 1986; Meijer 1999), this raises theoretical and methodological questions like: is it possible to generate a complete picture of a CPT? Which methods can be used to generate a CPT? How to deal with different schools of thought in a domain? When a PPT shows similarities with a CPT, is the PPT then indeed adequate for a specific task or situation? All in all, it seems either too complex to pay explicit attention to both the quality for a certain occupational domain as well as that for a particular professional situation. 
A constructivist perspective on learning and knowledge development increases the need for insight in personal professional knowledge development in competence-based vocational education. This article postulates that becoming a professional means constructing a PPT, in which different types of knowledge (such as formal knowledge, practical knowledge and work-process knowledge) and shared knowledge, norms, values and beliefs of a CPT are internalised. For further research it is recommended to develop valid and reliable methods that can be used to unravel and assess the development and qualities of students' PPTs in competence-based vocational education.

\section{References}

Achtenhagen, F., and N.W. Grubb. 2001. Vocational and occupational education: Pedagogical complexity, institutional diversity. In Handbook of research on teaching, ed. V. Richardson, 604-39. Washington, DC: AERA.

Anderson, J.R. 1980. Cognitive psychology and its implications. San Francisco, CA: W.H. Freeman.

Anderson, J.R., and C.D. Schunn. 2000. Implications of the ACT-R learning theory: No magic bullets. In Advances in instructional psychology. Vol. 5 of Educational design and cognitive science, ed. R. Glaser. London: Lawrence Erlbaum.

Anderson, J.R., L.M. Reder, and H.A. Simon. 1996. Situated learning and education. Educational Researcher 25: 5-11.

Argyris, C., and D.A. Schön. 1974. Theory in practice: Increasing professional effectiveness. San Francisco, CA: Jossey Bass Publishers.

Argyris, C., and D.A. Schön. 1978. Organizational learning; a theory of action perspective. Reading, MA: Addison-Wesley.

Atkinson, R.C., and R.M. Shiffrin. 1968. Human memory: A proposed system and its control processes. In The psychology of learning and motivation: Advances in research and theory, ed. K.W. Spence and J.T. Spence, 742-75. New York: Academic Press.

Baddely, A., and G. Hitch. 1974. Working memory. The Psychology of Learning and Motivation 8: 47-89.

Becker, F., and F. Steale. 1995. Workplace by design: Mapping high-performance workscape. San Francisco: Jossey-Bass.

Beijaard, D., and N. Verloop. 1996. Assessing teachers' practical knowledge. Studies in Educational Evaluation 22: 275-86.

Berliner, D.C. 1995. The nature of experience in teaching. In Effective and responsible teaching: The new synthesis, ed. F.K. Oser, A. Dick, and J.L. Patry, 227-48. San Francisco, CA: Jossey-Bass Publishers.

Biemans, H.J.A., L. Nieuwenhuis, R. Poell, M. Mulder, and R. Wesselink. 2004. Competence-based VET in the Netherlands: Backgrounds, pitfalls and implications. Journal of Vocational Education and Training 56: 523-38.

Billet, Stephen. 2000. Guided learning at work. Journal of Workplace Learning 12: 272-85.

Billet, Stephen. 2001. Learning in the workplace: Strategies for effective practice. Sydney, Crows Nest: Allen \& Unwin.

Boreham, Nicholas. 2002. Work process knowledge, curriculum control and the work-based route to vocational qualifications. British Journal of Educational Studies 50: 225-37.

Boreham, Nicholas. 2004. Orienting the work-based curriculum towards work process knowledge: A rationale and a German case study. Studies in Continuing Education 26: 209-27.

Boshuizen, H.P.A., and H.G. Schmidt. 1992. On the role of biomedical knowledge in clinical reasoning by experts, intermediates and novices. Cognitive Science, 16: 153-84.

Brown, J.S., A. Collins, and P. Duguid. 1989. Situated cognition and the culture of learning. Educational Researcher 18: 32-42.

Cornett, J., C. Yeoties, and L. Terwilliger. 1990. Teacher personal practise theories and their influences upon teacher curricular and instructional actions: A case study of a secondary science teacher. Science Education 74: 517-29.

Darling-Hammond, L., and G. Sykes. 1999. Teaching as the learning profession: Handbook of policy and practice. San Francisco, CA: Jossey-Bass Publishers. 
de Bruijn, E. 2004. Changing pedagogic and didactic approaches in vocational education in the Netherlands: From institutional interests to ambitions of students. European Journal of Vocational Training 31: 27-37.

de Bruijn, E., and L. Nieuwenhuis. 1994. Education between profession and market: The development of professional training. In Flexibility in training and vocational education, ed. W.J. Nijhof and J.N. Streumer, 109-33. Utrecht, the Netherlands: Lemma.

de Jong, T., and M.G.M. Ferguson-Hessler. 1996. Types and quantities of knowledge. Educational Psychologist 31: 105-13.

Drucker, Peter. 1993. Post-capitalist society. New York: Harper Business.

Eraut, Michael. 1994. Developing professional knowledge and competence. London: Falmer Press.

Fitts, P.M., and M.I. Posner. 1967. Human performance. Belmont, CA: Brooks/Cole Publishing Company.

Griffiths, T., and D. Guile. 2003. A connective model of learning: The implications for work process knowledge. European Educational Research Journal 2: 56-74.

Guile, D., and T. Griffiths. 2003. A connective model of learning: The implications for work process knowledge. European Educational Research Journal 2: 56-73.

Guile, D., and M. Young. 2003. Transfer and transition in vocational education: Some theoretical perspectives. In School and work: New perspectives on transfer and boundary-crossing, ed. T. Tuomi-Gröhn and Y. Engeström, 63-81. Amsterdam: Pergamon.

Hager, P., and A. Gonczi. 1991. Competency based standards: A boon for continuing professional education? Studies in Continuing Education 13: 24-40.

Hinton, G., and J. Anderson. 1981. Parallel models of associative memory. Hillsdale: Erlbaum.

Huijts, P.M., E. de Bruijn, and H. Schaap. Revealing Personal Professional Theories. Manuscript accepted for publication.

Illeris, Knud. 2003. Workplace learning and learning theory. Journal of Workplace Learning 15: $167-78$.

Kagan, Dona. 1990. Ways of evaluating teacher cognition: Interferences concerning the Goldilocks Principle. Review of Educational Research 60: 419-69.

Kelchtermans, G., and R. Vandenberghe. 1994. Teachers' professional development: A biographical perspective. Journal of Curriculum Studies 26: 45-62.

Kirschner, P.A., J. Sweller, and R.E. Clark. 2006. Why minimal guidance during instruction does not work: An analysis of the failure of constructivist, discovery, problem-based experiential and inquiry-based teaching. Educational Psychologist 41: 75-86.

Krause, F. 1986. Subjective theories of teachers: Reconstruction through stimulated recall, interview and graphic representation of teacher thinking. In Advances of research on teacher thinking, ed. M. Ben-Peretz, R. Bromme, and R. Halkes, 159-71. Lisse, the Netherlands: Swets and Zeitlinger.

Lave, J., and E. Wenger. 1991. Situated learning: Legitimate peripheral participation. Cambridge, UK: Cambridge University Press.

Levin, B., and Y. He. 2008. Investigating the content and sources of teacher candidates' personal practical theories. Journal of Teacher Education 59: 55-68.

Lizzio, A., and K. Wilson. 2004. Action learning in higher education: An investigation of its potential to develop professional capability. Studies in Higher Education 29: 469-88.

Maes, Martine. 2004. Vocational education and training in the Netherlands. CEDEFOP Panorama Series no. 96: 79. Luxembourg: Office for the Official Publications of the European Communities.

Mayer, R. 1981. The promise of cognitive psychology. San Francisco: Freeman.

Meijer, P.C. 1999. Teachers' practical knowledge: Teaching reading comprehension in secondary education. $\mathrm{PhD}$ diss., Leiden University.

Meijer, P.C., N. Verloop, and D. Beijaard. 2002. Multi-method triangulation in a qualitative study on teachers' practical knowledge: An attempt to increase internal validity. Quality and Quantity 36: 145-67.

Munby, H., T. Russell, and A.K. Martin. 2001. Teachers' knowledge of how it develops. In Handbook of research on teaching, ed. V. Richardson, 877-904. Washington, DC: AERA.

Nijhof, W., and W. van Esch. 2004. Unravelling policy, power, process and performance. The formative evaluation of the Dutch Adult and Vocational Education Act.'s Hertogenbosch: CINOP Expertisecentrum. 
Nonaka, I., and H. Takeuchi. 1995. The knowledge creating company: How Japanese companies create the dynamics of innovation. New York: Oxford University Press.

Pajares, Frank. 1992. Teachers' beliefs and educational research: Clearing up a messy construct. Review of Educational Research 62: 307-32.

Piaget, Jean. 1950. The psychology of intelligence in children. New York: Harcourt Brace.

Polanyi, Micheal. 1958. Personal Knowledge: Towards a Post Critical Philosophy. London: Routledge.

Polanyi, Michael. 1983. The tacit dimension. New York: Anchor Press.

Poortman, Cindy. 2007. Workplace learning in senior Secondary Vocational Education. PhD diss., Twente University.

Putnam, R., and H. Borko. 2000. What do new views of knowledge and thinking have to say about research on teacher learning? Educational Researcher 29: 4-15.

Rauner, Felix. 2007. Practical knowledge and occupational competence. European Journal of Vocational Education Training 40: 52-66.

Schön, Donald. 1983. The reflective practitioner: How professionals think in action. New York: Basic Books.

Seezink, A., R.F. Poell, and P.A. Kirschner. 2009. Teachers' individual action theories about competence-based education: The value of the cognitive apprenticeship model. Journal of Vocational Education and Training 61: 203-15.

Shulman, Lee. 2006. Professional education in comparative perspective: Medicine, nursing, law and engineering. Symposium at the conference of the American Educational Research Association, April 7-11, in San Francisco, CA.

Simons, P.R.J., J. van der Linden, and T. Duffy. 2000. New learning. Dordrecht, the Netherlands: Kluwer Academic Publishers.

Tillema, H., J.M.W. Kessels, and F. Meijers, F. 2000. Competencies as building blocks for integrating assessment with instruction in vocational education: A case from the Netherlands. Assessment and Evaluation in Higher Education 25: 265-78.

van der Krogt, F.J., and A.A. Vermulst. 2000. Beliefs about organizing learning: A conceptual and empirical analysis of managers' and workers' learning action theories. International Journal of Training and Development 4: 124-37.

van der Sanden, J.M.M., and C.C.J. Teurlings. 2003. Developing competence during practice periods: The learner's perspective. In Between school and work: New perspectives on transfer and boundary-crossing, ed. T. Tuomi-Gröhn and Y. Engeström, 119-38. Amsterdam: Pergamon.

van Oers, Bert. 1998. From context to contextualization. Learning and Instruction 8: 473-88.

van Zolingen, S., F. Blokhuis, W. Streumer, and W.J. Nijhof. 1999. Towards a method for the formulation of key qualifications and core problems. In Bridging the skills gap between work and education, ed. W.J. Nijhof and J. Brandsma, 115-38. Dordrecht, the Netherlands: Kluwer Academic Publishers.

Verloop, N., J. van Driel, and P. Meijer. 2001. Teacher knowledge and the knowledge base of teachers. International Journal of Educational Research 35: 441-61.

Vygotsky, Lev. 1978. Mind in society. Cambridge, MA: Harvard University Press.

Wagner, Peter. 1994. A sociology of modernity: Liberty and discipline. London: Routledge.

Weigel, T., M. Mulder, and K. Collins. 2007. The concept of competence in the development of vocational education and training in selected EU member states. Journal of Vocational Education and Training 59: 53-66.

Wenger, Etienne. 1998. Communities of practice: Learning, meaning, and identity. Cambridge, UK: Cambridge University Press.

Wilensky, Harold. 1964. The professionalization of everyone? American Journal of Sociology 70: $137-58$.

Winitzky, N., and D. Kauchak. 1995. Learning to teach: Knowledge development in classroom management. Teaching and Teacher Education 11: 215-27.

Zanting, A., N. Verloop, and J.D. Vermunt. 2003. Using interviews and concept maps to access mentor teacher practical knowledge. Higher Education 46: 195-214. 